\title{
STRATIGRAPHY OF PALEOGENE SEQUENCES IN WESTON - SIPITANG, SABAH
}

\author{
Tracy Binti Guan Leong*, Sanudin Hj. Tahir, Junaidi Asis \\ Geology Programme, Faculty of Science and Natural Resources, Universiti Malaysia Sabah, 88400 Kota Kinabalu, Sabah, Malaysia \\ *Corresponding Author Email: tracyguanleong@gmail.com
}

This is an open access article distributed under the Creative Commons Attribution License, which permits unrestricted use, distribution, and reproduction in any medium, provided the original work is properly cited

\section{ARTICLE DETAILS}

\section{Article History:}

Received 12 November 2017 Accepted 12 December 2017 Available online 1 January 2018

\section{ABSTRACT}

This study is aimed to renew the stratigraphy in Weston - Sipitang especially for Temburong Formation and Crocker Formation which are known as the Paleogene sequences. The interfingering relationship between Temburong Formation and Crocker Formation shows that the Temburong Formation is older than the Crocker Formation in terms of stratigraphic sequences which had been the opposite. Facies analysis, facies association studies and the correlation of lithostratigraphic units in the study area and earlier studies helped to interpret stratigraphy and renew the position of stratigraphic for the Paleogene sequences. Temburong Formation and Crocker Formation are dated as Upper Eocene to Lower Miocene age.

\section{KEYWORDS}

Temburong, Paleogene, Upper Eocene, Lower Miocene age, lithostratigraphic.

\section{INTRODUCTION}

The area of study comprising Weston to Sipitang is located in the southwest of Sabah (Figure 1) with latitude of $05^{\circ} 15^{\prime} \mathrm{N}$ to $05^{\circ} 01^{\prime} \mathrm{N}$ and longitude of $115^{0} 30^{\prime} \mathrm{E}$ to $115^{0} 39^{\prime} \mathrm{E}$. Area of study mapped in geological map (Figure 1) is $482.08 \mathrm{~km}^{2}$. This study focuses on Paleogene sequences consisting of Temburong Formation and Crocker Formation. Temburong Formation locality is located in Kg. Naluyan Besar (Tu), Kg. Sungai Tiga (T1, T2) and Kg. Ulu Sipitang (T/M) while Crocker Formation locality is located in Kg. Naparan (Cu, C1) and at Weston (C2).

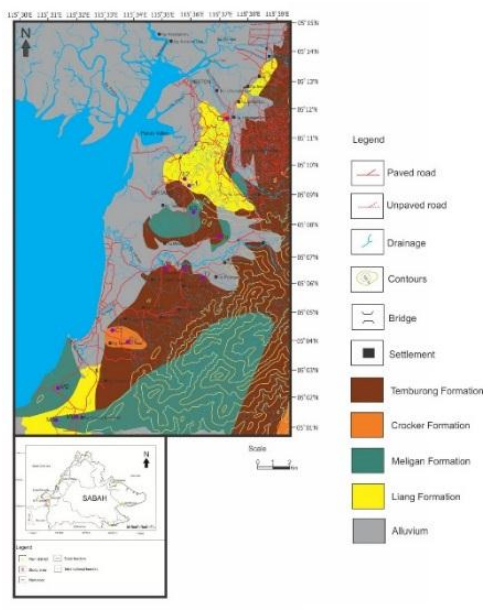

Figure 1: Geological map of study area and Sabah map [1].

\section{GENERAL GEOLOGY}

The older part of Setap Shale Formation experienced the same folding deformation with the West Crocker Formation and later named Temburong Formation [2]. Previous studies show that the Crocker Formation is a part of the Temburong Formation based on the similarity of the rock units found in both of these formations [3]. Both of these formations have interfingering relationship to one another with the same stratigraphic units ranging from Eocene to Miocene identified by the presence of foraminifera fossils [4]. In Sipitang area comprising the West Crocker Formation, there is no unconfirmity identified between the Crocker Formation and the Temburong Formation. The Crocker Formation is a turbidite sequence widely exposed along the west coast of Sabah with its major division classified as greywacke [5].

\section{RESEARCH METHOD}

Stratigraphic studies in the study area were focused on the study of lithostratigraphy through facies analysis and facies association studies. The method of lithostratigraphic unit's correlation was conducted by using lithology to determine the lateral distribution of facies and the change of facies. Stratigraphic studies were also described further in terms of stereotype and type locality, rock unit's relationship, fossil and the age of formation. The stratigraphic sequence model was constructed to describe the stratigraphic relationships between formations and also to explain the age of formations in study area.

\section{FACIES ANALYSIS AND FACIES ASSOCIATION}

The description of facies analysis and facies association can be found in Table 1.

Table 1: Facies analysis and facies association.

\begin{tabular}{|c|c|c|c|c|c|c|c|}
\hline \multirow[t]{2}{*}{ Rock Unit } & \multicolumn{3}{|c|}{ Facies Analysis } & \multicolumn{3}{|c|}{ Facies Association } & \multirow{2}{*}{$\begin{array}{c}\text { Deposition } \\
\text { Environment }\end{array}$} \\
\hline & Bed & Description & Interpretation & Type & Description & Interpretation & \\
\hline $\begin{array}{l}\text { Crocker } \\
\text { Formation }\end{array}$ & $\begin{array}{l}\mathrm{Ta}-\mathrm{Te} \\
\text { (channel) }\end{array}$ & $\begin{array}{l}\text { Bouma Ta is the } \\
\text { bed marker with } \\
\text { massive } \\
\text { structure. The } \\
\text { thickness of } \\
>1 \text { meter is } \\
\text { described as the } \\
\text { channel. }\end{array}$ & $\begin{array}{l}\text { It is deposited with } \\
\text { high density of } \\
\text { turbidite current. The } \\
\text { grains are deposited } \\
\text { at once as the current } \\
\text { power decreases to } \\
\text { form a massive layer. }\end{array}$ & Channel - levee & $\begin{array}{l}\text { Channel is marked } \\
\text { with the present of } \\
\text { bouma Ta. Massive } \\
\text { structure and levee } \\
\text { which is an } \\
\text { overflow of the } \\
\text { channel } \\
\text { characterized by } \\
\text { the presence of a }\end{array}$ & $\begin{array}{l}\text { Channel-levee can be } \\
\text { found in middle fan } \\
\text { of deep marine and is } \\
\text { affected by high } \\
\text { density turbidite } \\
\text { current and active } \\
\text { sediment deposition. }\end{array}$ & \\
\hline
\end{tabular}




\begin{tabular}{|c|c|c|c|c|c|c|c|}
\hline & & & & & $\begin{array}{l}\mathrm{Td} \quad \text { parallel } \\
\text { lamination. }\end{array}$ & & $\begin{array}{c}\text { Middle fan } \\
\text { (Deep marine) }\end{array}$ \\
\hline & $\begin{array}{l}\mathrm{Ta} / \mathrm{Tb}-\mathrm{Te} \\
\text { (channel) }\end{array}$ & $\begin{array}{l}\text { Bouma Ta is the } \\
\text { bed marker with } \\
\text { massive structure } \\
\text { and the thickness } \\
\text { of }>1 \text { meter. The } \\
\text { layer begin with } \\
\text { Ta or Tb. }\end{array}$ & $\begin{array}{l}\text { It is deposited with } \\
\text { high density of } \\
\text { turbidite current. The } \\
\text { grains are deposited } \\
\text { at once as the current } \\
\text { power decreases to } \\
\text { form a massive layer. }\end{array}$ & Channel - lobe & $\begin{array}{l}\text { Channel is marked } \\
\text { with the present of } \\
\text { bouma Ta and lobe } \\
\text { is marked with the } \\
\text { present of bouma } \\
\mathrm{Tb} \text { as the remains } \\
\text { from the channel. }\end{array}$ & $\begin{array}{l}\text { Channel-lobe can be } \\
\text { found in middle fan } \\
\text { of deep marine in a } \\
\text { state of high energy } \\
\text { flow regime. }\end{array}$ & \\
\hline & $\begin{array}{l}\mathrm{Ta} / \mathrm{Tb}-\mathrm{Te} \\
\text { (lobe) }\end{array}$ & $\begin{array}{l}\text { Bouma Tb which } \\
\text { has a parallel } \\
\text { lamination } \\
\text { structure is a lobe } \\
\text { indicator and a } \\
\text { layer that begins } \\
\text { with Ta or Tb. }\end{array}$ & $\begin{array}{l}\text { It is deposited in a } \\
\text { state of higher flow } \\
\text { regime with high } \\
\text { energy to transport } \\
\text { sand grains with } \\
\text { traction. }\end{array}$ & \multirow[t]{2}{*}{$\begin{array}{l}\text { Channel - lobe } \\
\text { (sediment } \\
\text { migration) }\end{array}$} & \multirow{2}{*}{$\begin{array}{l}\text { Channel is marked } \\
\text { with the present of } \\
\text { bouma Ta and lobe } \\
\text { (sediment } \\
\text { migration) is } \\
\text { marked with the } \\
\text { present of bouma } \\
\text { Tc with cross } \\
\text { lamination } \\
\text { structure. Channel } \\
\text { is deposited on the } \\
\text { lobe (sediment } \\
\text { migration). }\end{array}$} & \multirow{2}{*}{$\begin{array}{l}\text { Lobe (sediment } \\
\text { migration) is } \\
\text { deposited on the } \\
\text { edge of the middle } \\
\text { fan after undergoing } \\
\text { a transition of } \\
\text { sediment deposition } \\
\text { with low energy of } \\
\text { lower flow regime. } \\
\text { Channel is deposited } \\
\text { on top of it with high } \\
\text { energy. }\end{array}$} & \\
\hline & Tb- Te (lobe) & $\begin{array}{l}\text { Bouma } \mathrm{Tb} \text { with } \\
\text { the parallel } \\
\text { lamination } \\
\text { structure is the } \\
\text { lobe indicator. }\end{array}$ & $\begin{array}{l}\text { It is deposited in a } \\
\text { state of higher flow } \\
\text { regime with high } \\
\text { energy. }\end{array}$ & & & & \\
\hline \multirow[t]{2}{*}{ Rock Unit } & \multicolumn{3}{|l|}{ Facies Analysis } & \multicolumn{3}{|c|}{ Facies Association } & \\
\hline & Bed & Description & Interpretation & Type & Description & Interpretation & Environment \\
\hline \multirow[t]{3}{*}{$\begin{array}{l}\text { Crocker } \\
\text { Formation }\end{array}$} & Td - Te (levee) & $\begin{array}{l}\text { Bouma Td with } \\
\text { parallel } \\
\text { lamination } \\
\text { structure is the } \\
\text { indicator of levee } \\
\text { which is the } \\
\text { overflow from } \\
\text { channel. }\end{array}$ & $\begin{array}{l}\text { It is deposited with } \\
\text { very little turbidite } \\
\text { current flow. A slight } \\
\text { change in the current } \\
\text { causes } \\
\text { lamination } \\
\text { deposition of coarse } \\
\text { and fine grains } \\
\text { alternately. }\end{array}$ & \multirow[b]{2}{*}{$\begin{array}{l}\text { Lobe - lobe } \\
\text { (sediment } \\
\text { migration) }\end{array}$} & \multirow{2}{*}{$\begin{array}{l}\text { Lobe is marked } \\
\text { with the present of } \\
\text { bouma Tb with } \\
\text { parallel lamination } \\
\text { structure. Lobe } \\
\text { (sediment } \\
\text { migration) is } \\
\text { marked with the } \\
\text { present of bouma } \\
\text { Tc with cross } \\
\text { lamination stren and also } \\
\text { structure an the } \\
\text { a part of the } \\
\text { sediment from the } \\
\text { lobe. }\end{array}$} & \multirow{2}{*}{$\begin{array}{l}\text { Lobe is deposited in } \\
\text { the middle fan of } \\
\text { deep marine with } \\
\text { high energy flow as a } \\
\text { part of the sediment } \\
\text { from the channel. } \\
\text { Lobe (sediment } \\
\text { migration) is } \\
\text { deposited on the } \\
\text { edge of the middle } \\
\text { fan after undergoing } \\
\text { a transition of } \\
\text { sediment deposition } \\
\text { with low energy of } \\
\text { lower flow regime. }\end{array}$} & \multirow[t]{2}{*}{$\begin{array}{l}\text { Middle fan } \\
\text { (deep marine) }\end{array}$} \\
\hline & $\begin{array}{l}\text { Tc - Te (lobe } \\
\text { (sediment } \\
\text { migration)) }\end{array}$ & $\begin{array}{l}\text { Bouma Tc with } \\
\text { cross lamination } \\
\text { structure } \\
\text { undergone } \\
\text { sediment } \\
\text { migration. }\end{array}$ & $\begin{array}{l}\text { It is deposited in } \\
\text { lower flow regime } \\
\text { with enough energy } \\
\text { to transport fine } \\
\text { sand. }\end{array}$ & & & & \\
\hline & $\begin{array}{l}\text { Tc -Te } \\
\text { (migration lobe) }\end{array}$ & $\begin{array}{l}\text { Bouma Tc with } \\
\text { cross lamination } \\
\text { structure. }\end{array}$ & $\begin{array}{l}\text { It is deposited in } \\
\text { lower flow regime } \\
\text { with enough energy } \\
\text { to transport fine } \\
\text { sand. }\end{array}$ & Migration lobe & $\begin{array}{l}\text { Migration lobe is } \\
\text { marked with the } \\
\text { present of bouma } \\
\text { Tc with cross } \\
\text { lamination } \\
\text { structure. }\end{array}$ & $\begin{array}{l}\text { Migration lobe is } \\
\text { deposited in the } \\
\text { outer fan of deep } \\
\text { marine with lower } \\
\text { flow regime with } \\
\text { very little current } \\
\text { flow. }\end{array}$ & $\begin{array}{l}\text { Outer fan } \\
\text { (deep marine) }\end{array}$ \\
\hline $\begin{array}{l}\text { Temburong } \\
\text { Formation }\end{array}$ & $\begin{array}{l}\text { Tc }- \text { Te (distal } \\
\text { lobe) }\end{array}$ & $\begin{array}{l}\text { Bouma Tc with } \\
\text { cross lamination } \\
\text { structure. }\end{array}$ & $\begin{array}{l}\text { It is deposited in } \\
\text { lower flow regime } \\
\text { with enough energy } \\
\text { to transport fine } \\
\text { sand. }\end{array}$ & Distal lobe & $\begin{array}{l}\text { Distal lobe is } \\
\text { marked with the } \\
\text { present of bouma } \\
\text { Tc with cross } \\
\text { lamination } \\
\text { structure. }\end{array}$ & $\begin{array}{l}\text { Distal lobe is } \\
\text { deposited in the } \\
\text { outer fan of deep } \\
\text { marine with lower } \\
\text { flow regime with } \\
\text { very little current } \\
\text { flow. }\end{array}$ & $\begin{array}{l}\text { Outer fan } \\
\text { (deep marine) }\end{array}$ \\
\hline
\end{tabular}

\begin{tabular}{|c|c|c|c|c|c|c|c|}
\hline \multirow[t]{2}{*}{ Rock Unit } & \multicolumn{3}{|c|}{ Facies Analysis } & \multicolumn{3}{|c|}{ Facies Association } & \multirow{2}{*}{$\begin{array}{c}\text { Deposition } \\
\text { Environment }\end{array}$} \\
\hline & Bed & Description & Interpretation & Type & Description & Interpretation & \\
\hline $\begin{array}{l}\text { Temburong } \\
\text { Formation }\end{array}$ & $\begin{array}{l}\mathrm{Te} \text { (basin } \\
\text { plain) }\end{array}$ & $\begin{array}{l}\text { Bouma Te has no } \\
\text { structure } \quad \text { and } \\
\text { sequence. }\end{array}$ & $\begin{array}{l}\text { It is deposited with } \\
\text { very little current } \\
\text { flow. }\end{array}$ & Basin plain & $\begin{array}{l}\text { Basin plain is } \\
\text { marked with the } \\
\text { present of bouma } \\
\text { Te without any } \\
\text { sediment } \\
\text { structure. }\end{array}$ & $\begin{array}{l}\text { It is deposited in the } \\
\text { basin plain with very } \\
\text { little current flow. }\end{array}$ & Basin plain \\
\hline
\end{tabular}

\section{CORRELATION OF LITHOSTRATIGRAPHIC UNITS AND} DEPOSITION ENVIRONMENT

\subsection{Temburong Formation}

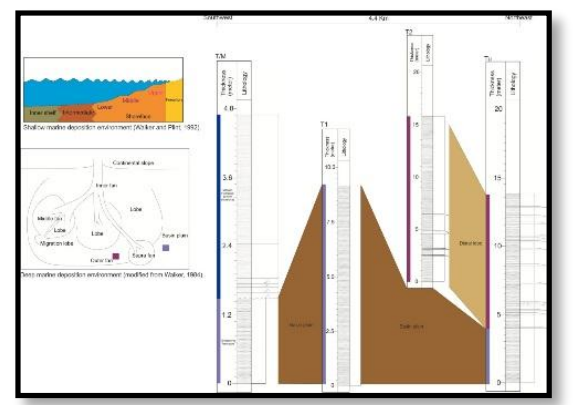

Figure 2: Correlation of Temburong Formation and deposition environment.

\section{Description:}

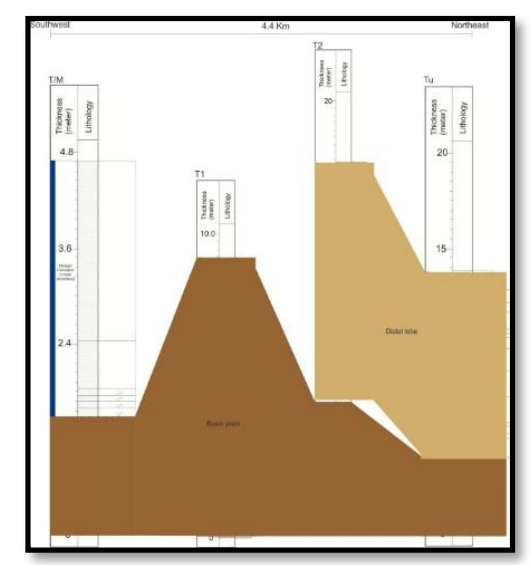




\subsection{Crocker Formation}

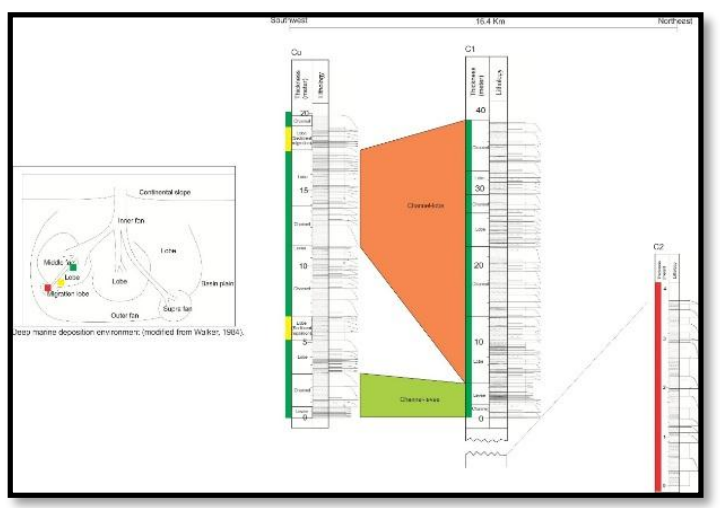

Figure 3: Correlation of Crocker Formation and deposition environment.

Description:

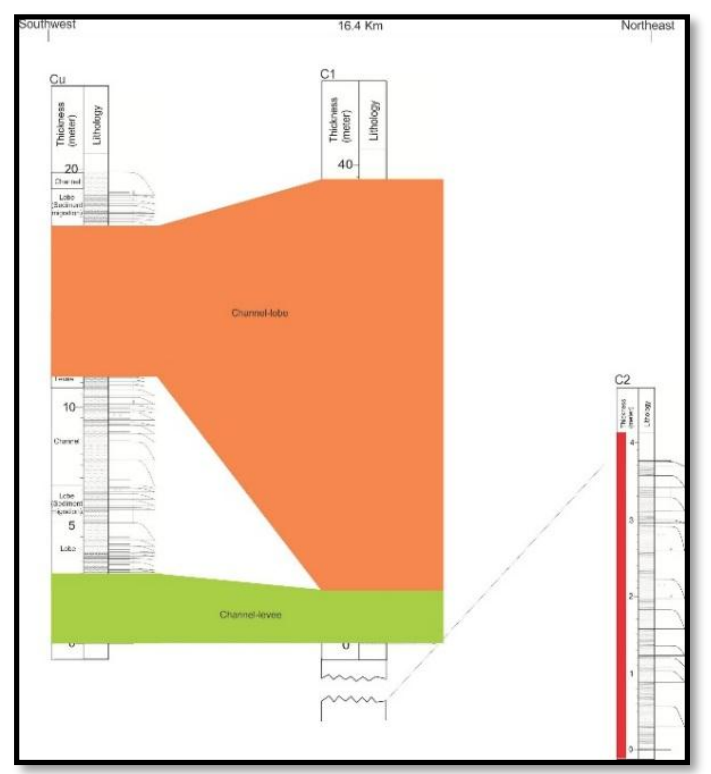

\section{THE RELATIONSHIP BETWEEN TEMBURONG FORMATION AND} CROCKER FORMATION CAUSED BY REGRESSION PROCESS

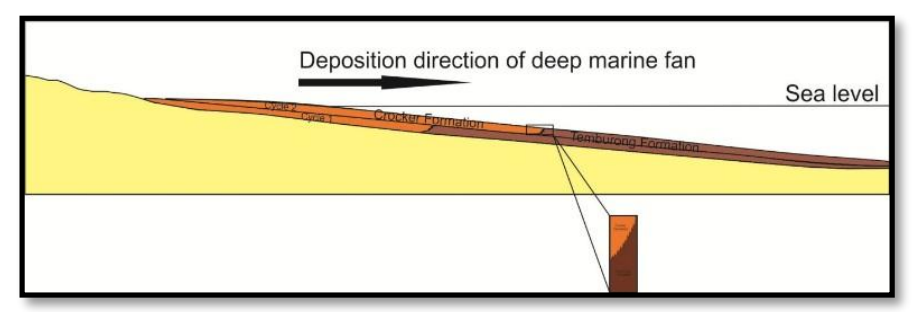

Figure 4: The cycle sequence deposition of Temburong Formation and Crocker Formation.

\section{STRATIGRAPHY}

The description of stratotype, rock unit relationship, fossil and age are essential to further explain the stratigraphy in the study area.

\subsection{Stratotype and Type Locality}

For the Temburong Formation, there is no record for stratotype. However, the type locality of the Temburong Formation lies at the head of the river of Temburong river in Brunei [2]. The formation originates from Brunei Darussalam. According to a study, the stratotype for the Crocker Formation is located at Tenom Gorge [6]. There is no type locality record for the Crocker Formation. The origin of the Crocker Formation is located in the Crocker range at the western part of Sabah [7].

\subsection{The Relationship of Rock Units}

Temburong formation with the age of Upper Eocene to Lower Miocene is associated with six types of formations, which are the Crocker Formation, Meligan Formation, Setap Shale Formation, Mulu Formation, Kelalan Formation and Tubau Formation. In the study area, the interfingering relationship between Temburong Formation and Crocker Formation cannot be found. It can be found in Tenom which is also located in the southwestern part of Sabah [8]. There are nine formations that have a relationship with the Crocker Formation which has the same age as the Temburong Formation. Among them are the Trusmadi Formation, Pinosuk Gravel Formation, Chert-spilit Formation, Bongaya Formation Kudat Formation, Temburong Formation, Meligan Formation, Belait Formation and Labang Formation.

\subsection{Fossil and Age}

The research on biostratigraphy for microfossil cannot be carried out because there is no trace of any microfossil in microfossil analysis. Therefore, only the lithostratigraphy study was concentrated. Due to this situation, no microfossil is observed in the study area. However, microfossil for rock units can be explained by reference to previous studies. Only trace fossil can be observed in the study area. For the Temburong Formation, no trace fossil can be found in the study area. However, there is a previous study record for the microfossil of Temburong Formation in the Tenom district which is also located in southwest of Sabah. There is a planktic foraminifera representing two biozones named Globorotalia ciperoensis zone (Upper Oligocene) and Catapsydrax dissimilis zone - Praeorbulina sicana (Lower Miocene) which are in the range of Upper Eocene to Lower Miocene age [9]. For the Crocker Formation, the trace fossil of Helminthopsis sp. can be found which proves that the Crocker Formation is deposited in the deep marine environment. There is a previous study record for the planktonic foraminifera of Crocker Formation named Globigerinoides sp. in the Tenom area which is also located in southwest of Sabah with the same age as the Temburong Formation [8].

\section{STRATIGRAPHIC SEQUENCE MODEL}

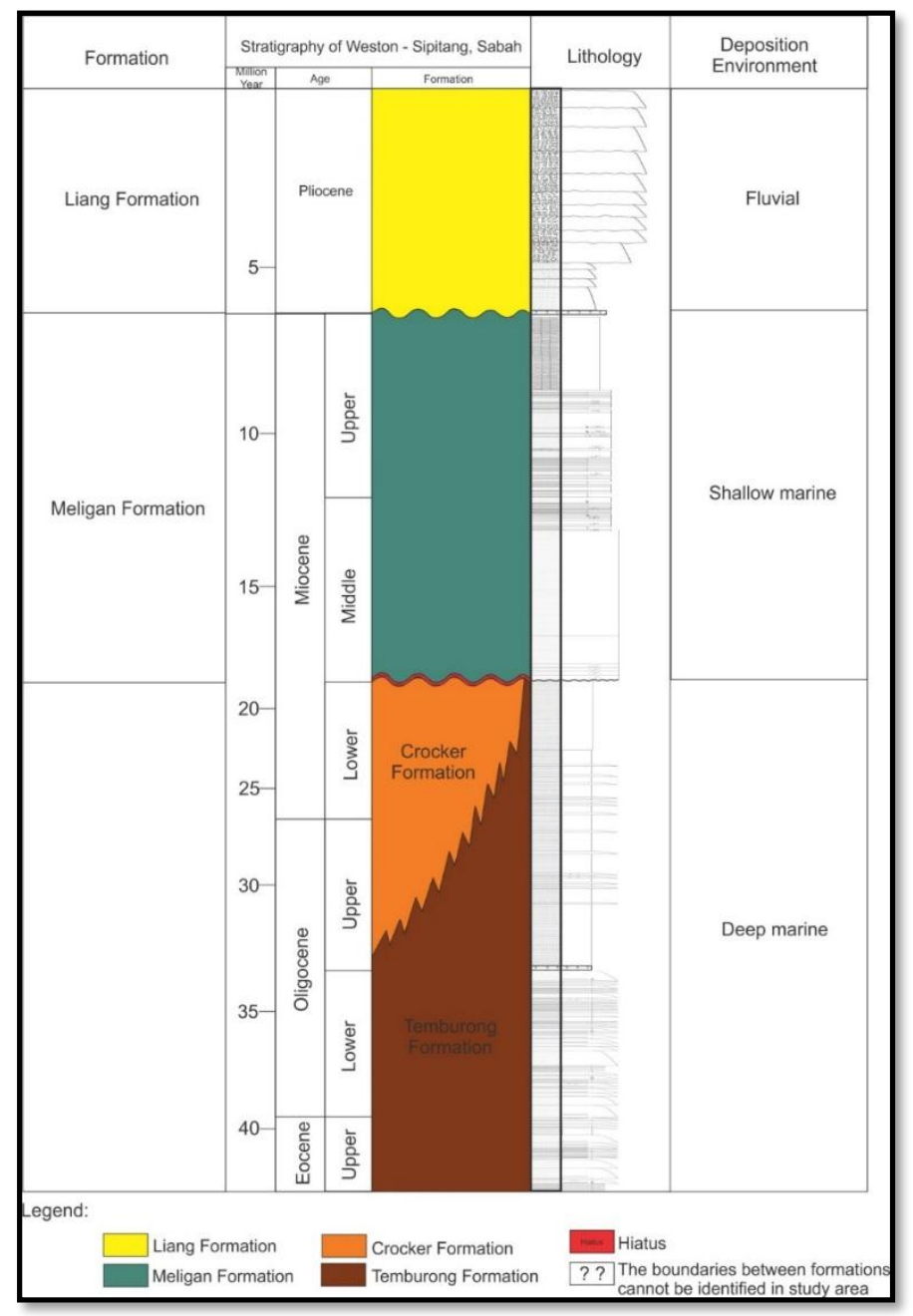

Figure 5: Stratigraphic sequence model of Weston - Sipitang, Sabah [4]

\section{CONCLUSION}


The interfingering relationship between Temburong Formation and Crocker Formation concluded that Temburong Formation is older than Crocker Formation in terms of stratigraphic sequence which had been the opposite. Both of these formations are dated as Upper Eocene to Lower Miocene.

\section{REFERENCE}

[1] Wilson, R.A.M. 1964. Geological Map of Labuan and Padas Valley area Sabah. Geological Survey Borneo Region, Malaysia.

[2] Brondijk, J.F. 1962. Reclassification of Part of The Setap Shale Formation as Temburung Formation, British Borneo Geological Survey Annual Report: ms 56-60. Blackwell Scientific Publications, Oxford, 103122.

[3] Wilson, R.A.M. 1964. The Geology and Mineral Resources of The Labuan and Padas Valley Area, Sabah, Malaysia. Geological Survey Borneo Region, Malaysia, Memoir. 1150.

[4] Bowen, J.M., Wright, J.A. 1957. Geology of Crocker Range and adjoining areas. In Leichti (Phty.) Geology of Sarawak, Brunei and Northwest Sabah. Br\#. Ten. Borneo Geol. Survey Dept. 3.

[5] Tahir, S.H., Musta, B. 2007. Pengenalan Kepada Stratigrafi. Kota Kinabalu: Universiti Malaysia Sabah.

[6] Wilson, R.A.M., Wong, N.P.Y. 1964. The Geology and Mineral Resources of The Labuan and Padas Valley Area Sabah, Malaysia. Memoir 17 Geological Survey Borneo Malaysia: p 150.

[7] Lee C.P., Leman, M.S., Hassan, K., Nasib, B.M., Karim, R. 2004. Stratigraphic Lexicon of Malaysia. Kuala Lumpur: Geological Society of Malaysia.

[8] Rahman, M.N.I.A. 2014. Analisis Fasies dan Kajian Diagenesis Formasi Crocker dan Formasi Temburong di Tenom, Sabah. Tesis Master. Universiti Malaysia Sabah.

[9] Asis, J., Rahman, M.N.I.A., Jasin, B., Tahir, S. 2015. Late Oligocene and Early Miocene planktic foraminifera from the Temburong Formation, Tenom, Sabah. Bulletin of the Geological Society of Malaysia, 61, 43-47. 